\title{
A poesia de Cacaso
}

Adilson Citelli*

Professor titular do Departamento de Comunicações e Artes da ECA/USP, onde ministra cursos de graduação e pós-graduação. Orienta dissertações e teses nas áreas de Comunicação e Linguagem, com ênfase nas subáreas Comunicação/Educação, Comunicação/Linguagem. É coeditor da revista Comunicação \& Educação, bem como pesquisador $1 C$ do CNPq. ** E-mail: citelli@uol.com.br

Cacaso nasceu Antônio Carlos Ferreira de Brito, em 1944, na cidade de Uberaba (MG), filho de Carlos Ferreira de Brito e Wanda Aparecida Lóes de Brito. Aos 11 anos, muda-se para o Rio de Janeiro, onde, um ano depois, é matéria de jornal em razão de suas caricaturas de políticos e personagens da vida pública.

Em 1964, ingressa no curso de Filosofia da Universidade Federal do Rio de Janeiro. Entre 1965 e 1975 leciona Teoria Literária na Pontifícia Universidade Católica do Rio de Janeiro. Pela FFLCH/USP obteve o título de mestre em Teoria Literária e Literatura Comparada. Tendo estudado violão clássico, Cacaso especializa-se na área jornalística de música e atua no Jornal do Brasil, O Estado de S. Paulo, Gazeta Mercantil e O Dia. Em 1967, ainda usando o nome Antônio Carlos de Brito, publica o seu primeiro livro de poemas: A palavra cerzida. No ano seguinte, passa a colaborar com os jornais Opinião e Movimento e participa ativamente dos movimentos de resistência à ditadura militar. Em 1974, publica Grupo escolar, com textos postos em uma linhagem que seria chamada de poesia marginal. Seguem-se, ainda, os livros de poemas Beijo na boca (1975), Segunda classe, em parceria com Luís Olavo Fontes (1975), Na corda bamba (1978), 3 poetas, em parceria com Eudoro Augusto e Letícia Moreira de Souza (1979), Mar de mineiro (1982), e a coletânea Beijo na boca e outros poemas (1985).

Junto às atividades de docente, ensaísta e poeta, Cacaso dedicou-se à música popular brasileira, compondo letras para, entre outros, Edu Lobo, Sueli Costa, Elton Medeiros, Danilo Caymmi, Maurício Tapajós e Sivuca. Em 1987, no Rio de Janeiro, morre de enfarte. Dez anos após sua morte, é publicada a coletânea de ensaios, poemas inéditos, crônicas e artigos saídos em jornais, Não quero prosa, com seleção e organização de Vilma Arêas.

\section{POESIA MARGINAL}

O autor fazia parte da geração de poetas surgida na virada de década de 1960 para 1970 e que se atribuiu o epíteto de poesia marginal ou nova poesia. Como o mercado editorial não conseguia absorver a grande quantidade de poetas surgidos à época, os textos eram confeccionados artesanalmente e distribuídos nas ruas pelos próprios autores. Além dessa experiência de produção

\footnotetext{
* Com a colaboração de Cristine Vargas (revista Comunicação \& Educação - ECA/USP e FFLCH/ USP).

** É autor de inúmeros artigos e livros, dentre os quais se destacam: Linguagem e persuasão (Ática: 1994); Comunicação e educação: a linguagem em movimento (Senac: 2000); Palavras, meios de comunicação e educação (Cortez: 2006).
} 
independente, os poetas "marginais" tinham como tema recorrente os fatos corriqueiros; no plano expressivo não adotavam critérios de rigorismo formal. Tal tendência, além de Cacaso, era seguida por nomes como: Ana Cristina César, Paulo Leminski, Ricardo Carvalho Duarte (Chacal) e Francisco Alvim.

Cacaso integra a geração da poesia marginal não só como poeta mas também como crítico, sendo considerado o grande teórico legitimador desta tendência poética.

A poesia de Cacaso, assim como a chamada poesia marginal, não apresentava características padronizadas, propondo a expressão livre, a inventividade e a crítica ao contexto político repressivo sustentado pela ditadura militar.

Como ensaísta, professor de literatura, Cacaso era conhecedor da tradição poética e realizava com extrema habilidade apropriações intertextuais e interdiscursivas, fazendo nascer deste jogo dialógico vários de seus poemas. Em Há uma gota de sangue no Cartão Postal, é possível observar o acionamento de tal estratégia discursiva:

Há uma Gota de Sangue no Cartão Postal

eu sou manhoso eu sou brasileiro

finjo que vou mas não vou minha janela é

a moldura do luar do sertão

a verde mata nos olhos verdes da mulata

sou brasileiro e manhoso por isso dentro

da noite e de meu quarto fico cismando na beira de um rio

na imensa solidão de latidos e araras

lívido

de medo e de amor.

\section{REFERÊNCIAS BIBLIOGRÁFICAS}

BRITO, Antonio Carlos de. Beijo na boca e outros poemas. São Paulo: Brasiliense, 1985 .

PROVASE, Lucius. Da experiência de escrever ao ato da escrita: vida e arte na poética de Cacaso. 2010. 86f. Dissertação (Mestrado em Letras) - Universidade de São Paulo, São Paulo, 2007.

1. BRITO, Antonio Carlos de. Beijo na boca e outros poemas. São Paulo: Brasiliense, 1985. p. 84. 